Combined bound water and water vapour diffusion of Norway spruce and European beech in and between the principal anatomical directions

\author{
Journal Article \\ Author(s): \\ Sonderegger, Walter; Vecellio, Manuele; Zwicker, Pascal; Niemz, Peter \\ Publication date: \\ 2011-10 \\ Permanent link: \\ https://doi.org/10.3929/ethz-b-000039722 \\ Rights / license: \\ In Copyright - Non-Commercial Use Permitted \\ Originally published in: \\ Holzforschung 65(6), https://doi.org/10.1515/HF.2011.091
}




\section{Combined bound water and water vapour diffusion of Norway spruce and European beech in and between the principal anatomical directions}

\author{
Walter Sonderegger*, Manuele Vecellio, Pascal \\ Zwicker and Peter Niemz \\ Department of Civil, Environmental and Geomatic \\ Engineering, Institute for Building Materials, ETH Zurich, \\ Zurich, Switzerland \\ * Corresponding author. \\ Department of Civil, Environmental and Geomatic Engineering, \\ Institute for Building Materials, ETH Zurich, 8093 Zurich, \\ Switzerland \\ Phone: +41-44-632-6924 \\ Fax: +41-44-632-1174 \\ E-mail: wsonderegger@ethz.ch
}

\begin{abstract}
The combined bound water and water vapour diffusion of wood is of great interest in the field of building physics. Due to swelling stresses, the steady-state-determined diffusion coefficient clearly differs from the unsteady-state-determined diffusion coefficient. In this study, both diffusion coefficients and the water vapour resistance factor of Norway spruce (Picea abies [L.] Karst.) and European beech (Fagus sylvatica L.) were investigated for the principal anatomical directions (radial, tangential and longitudinal) and in $15^{\circ}$ steps between these directions. The values were determined with the cup method as the basic principle. The unsteadystate-determined diffusion coefficient is, independent of the direction, about half that of the steady-state-determined diffusion coefficient. Both diffusion coefficients are about two to three times higher for spruce than for beech. They are up to 12 times higher in the longitudinal direction than perpendicular to the grain for spruce, and up to 15 times higher for beech. With increasing moisture content, the diffusion coefficients exponentially increase. The water vapour resistance factor shows converse values to the diffusion coefficients.
\end{abstract}

Keywords: beech; bound water diffusion; cup method; sorption; spruce; water vapour diffusion; water vapour resistance factor.

\section{Introduction}

Wood and wood composites are renewable materials produced with a low grey energy input. They are increasingly important in civil engineering. For example, novel woodbased wall constructions made of solid wood (such as cross laminated timber or wooden walls connected with dowels or nails) are currently being developed (Joščák et al. 2010). For wood as an anisotropic and hygroscopic material, accurate knowledge of the moisture flux in and also between the principal anatomical directions is important for precise structuralphysical calculations and for numerical modelling. Wood in wall constructions and wood-based panels can be aligned with different grain and ring angles, for example, in the novel product 'DendroLight' (Hofstetter et al. 2009).

Three types of moisture flux are conceivable in wood. Above the fibre saturation point (FSP), the flux is mainly effected by free water. Below the FSP, diffusion processes occur under the combined participation of bound water and water vapour: the former takes place within the cell walls and the latter within the cell lumens via pit openings. The ratio of these diffusion types strongly depends on the moisture content (MC), temperature, species, and the anatomical direction. Diverse authors have attempted to investigate both diffusion processes separately (Stamm 1959; Stamm 1960a; Stamm 1960b; Mouchot et al. 2006). This knowledge found acceptance in numerous diffusion models based on the cellular wood structure (Choong 1965; Siau 1995; Frandsen et al. 2007; Kang et al. 2008; Eitelberger and Hofstetter 2010; Hozjan and Svensson 2011).

The effective diffusion (i.e., the combined diffusion of bound water and water vapour) is of primary interest for physical calculation in wood buildings. To this purpose, two methods are established: the cup method and the sorption method (Olek 2003). The cup method according to ISO 12572 (2001) is used to measure the steady-state (SS) moisture transport in wood according to Fick's first law. The sorption method determines the diffusion coefficient at unsteady-state (US) conditions according to Fick's second law. Unfortunately, the results of the two methods can differ up to a factor of 10 (Wadsö 1993; Pfriem 2006), especially due to swelling stresses (Comstock 1963).

Hence, for calculations in the field of building physics, both diffusion coefficients are required. The SS-determined diffusion coefficient is useful to calculate the moisture gradient through external walls and the risk of condensation. The US-determined diffusion coefficient is required to describe short-term water storage and loss and the penetration depth at alternating indoor climates.

Water diffusion coefficients were frequently described in the last six decades for various woods. However, the data were obtained with different methods and are not always free of contradictions. While water diffusion in the principal wood directions is better studied, experimental data for offaxis diffusion (between the main directions) are not available from literature, though the influence of the grain angle on 
mechanical wood properties was determined by Hankinson (1921).

In this study, Norway spruce (Picea abies [L.] Karst.) and European beech (Fagus sylvatica L.) are in focus; the diffusion coefficients were revisited for the combined diffusion of bound water and water vapour, at SS and US conditions. For a better reliability, both diffusion coefficients were determined on the same specimens. Moreover, the water vapour resistance factor was also investigated. To take the anisotropic characteristics of wood into account, measurements were carried out not only in the three principal directions, radial (R), tangential $(\mathrm{T})$, and longitudinal (L), but also between them in $15^{\circ}$ steps. The main focus was laid on these off-axis directions.

\section{Material and methods}

\section{Material}

Cylindrical samples (diameter $140 \mathrm{~mm}$, thickness $20 \mathrm{~mm}$ ) of adult wood from European beech and Norway spruce were tested. Beech was cut from one stem and spruce from two stems from the region of Zurich. Thereby, the direction of the sample thickness corresponded to the investigated anatomical direction. Water vapour resistance and combined water vapour and bound water diffusion were determined in the three principal anatomical directions $(\mathrm{R}, \mathrm{T}$, and $\mathrm{L}$ ) and between them in $15^{\circ}$ steps so that a total of 18 directions were considered. Three specimens per species, direction and climate (see below) were tested.

\section{Experimental setup}

Water vapour resistance was determined according to ISO 12572 (2001) under 'dry cup' and 'wet cup' conditions. Here, the water vapour flow through a specimen, which is exposed to two different partial vapour pressures inside and outside the cup, is tested. The ambient air was conditioned to $20^{\circ} \mathrm{C}$ and $65 \%$ relative humidity $(\mathrm{RH})$, whereas, within the cup, a desiccant with almost $0 \% \mathrm{RH}$ for the 'dry cup' tests and desalinated water with almost $100 \%$ RH for the 'wet cup' tests were used. Additionally, 'dry cup' and 'wet cup' tests at drier ambient air conditions $\left(20^{\circ} \mathrm{C}\right.$ and $\left.35 \% \mathrm{RH}\right)$ were carried out for the specimens with the diffusion direction oriented perpendicular to the grain.

The specimens were first stored at $20^{\circ} \mathrm{C} / 65 \% \mathrm{RH}$ or $20^{\circ} \mathrm{C} / 35 \%$ $\mathrm{RH}$, respectively, until they reached equilibrium moisture content (EMC). For the tests (Figure 1), they were then put on top of a glass vessel filled up to $20 \mathrm{~mm}$ under the brim with either a desiccant (silica gel) or totally desalinated water. The specimens were laterally sealed with a tight-fitting circular rubber band. To measure the water sorption, from which the diffusion coefficient at US conditions was calculated, the specimens were weighed at defined intervals (by detaching the rubber band from the specimen) until they finally reached the EMC of the differentiating climate. Thereafter, the diffusion and water vapour resistance was measured at SS conditions, at which the vessels with the specimens were weighed five times with an interval of at least one day between two weighings.

\section{Determination of the water vapour resistance}

The water vapour resistance factor was calculated according to Annex G of ISO 12572 (2001) taking into account the thickness of the air layer in the test cup between the base of the specimen and

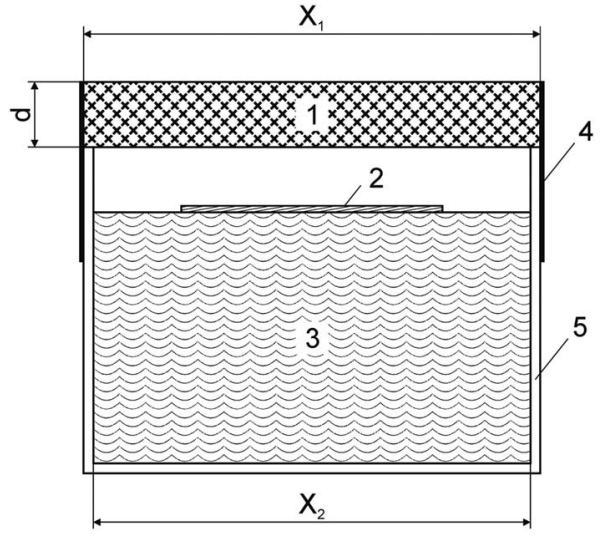

Figure 1 Test assembly for the 'dry cup' and 'wet cup' tests. 1, specimen with $X_{1}$ and $X_{2}$ as the upper and lower exposed area and with thickness d; 2, wood chip (used in 'dry cup' tests); 3, desiccant/ desalinated water; 4 , rubber band; 5 , glass vessel.

the desiccant or the desalinated water (Sonderegger and Niemz 2009):

$\mu=\frac{\delta_{a}}{d} \cdot\left(\frac{A \cdot \Delta p_{v}}{G}-\frac{d_{a}}{\delta_{a}}\right)$

where $\mu$ is the water vapour resistance factor $(-), \delta_{a}$ the water vapour permeability of air with respect to the partial vapour pressure $\left(\mathrm{kg} \mathrm{m}^{-1} \mathrm{~s}^{-1} \mathrm{~Pa}^{-1}\right), d$ the mean thickness of the specimen (m), $A$ the circular area of the specimen $\left(\mathrm{m}^{2}\right), \Delta p_{v}$ the water vapour pressure difference across the specimen $(\mathrm{Pa}), G$ the water vapour flow rate through the specimen $\left(\mathrm{kg} \mathrm{s}^{-1}\right)$, and $d_{a}$ the thickness of the air layer in the test cup between the base of the specimen and the desiccant or the desalinated water $(\mathrm{m})$.

\section{Determination of the diffusion coefficient at steady-state conditions}

The diffusion coefficient derived from the water vapour permeability at SS conditions according to ISO 12572 (2001) was determined according to Siau (1995):

$D_{S S}=\frac{\delta_{p} \cdot p_{o} \cdot V}{w_{o}} \cdot \frac{\partial H}{\partial M}$

where $D_{S S}$ is the diffusion coefficient at steady-state conditions $\left(\mathrm{m}^{2} \mathrm{~s}^{-1}\right), \delta_{p}\left(=\delta_{\mathrm{a}} / \mu\right)$ the water vapour permeability with respect to the partial vapour pressure $\left(\mathrm{kg} \mathrm{m}^{-1} \mathrm{~s}^{-1} \mathrm{~Pa}^{-1}\right), p_{o}$ the saturated water vapour pressure $(\mathrm{Pa}), V$ the volume of the specimen at standard climatic conditions $\left(\mathrm{m}^{3}\right), w_{o}$ the ovendry mass of the specimen $(\mathrm{kg})$, $\partial H$ the difference of RH (\%), and $\partial M$ the difference of MC (\%). For Eq. (2), a MC of $30 \%$ was assumed for both wood species at $100 \% \mathrm{RH}$.

\section{Determination of the diffusion coefficient at unsteady-state conditions}

According to Klopfer (1974) it is possible to determine a water absorption coefficient below FSP for the combined bound water and water vapour diffusion analogously to the capillary water absorption of liquid water (ISO 15148 2002). By neglecting the mass of water vapour, the absorption is carried out solely as bound water: 


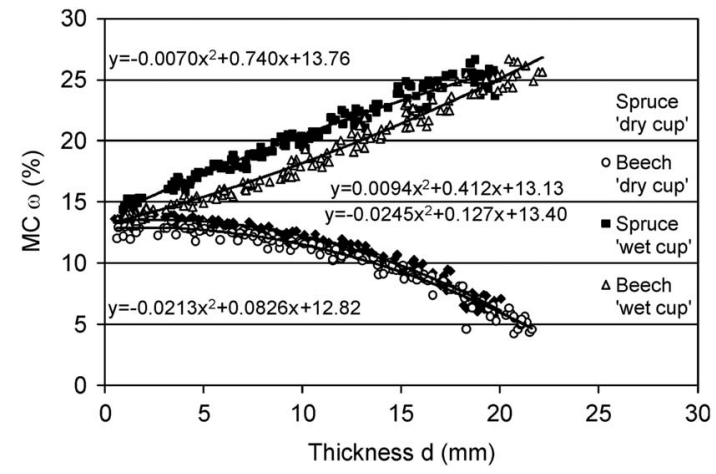

Figure 2 Distribution of MC $\omega$ over specimen thickness d at final conditions after the cup tests [according to Zwicker (2008), modified].

$A_{b w}=\frac{\Delta m}{A \cdot \sqrt{t}}$

where $A_{b w}$ is the water absorption coefficient of bound water $\left(\mathrm{kg} \mathrm{m}^{-2} \mathrm{~s}^{-0.5}\right), \Delta m$ the mass gain $(\mathrm{kg}), A$ the face area $\left(\mathrm{m}^{2}\right)$, and $t$ the time (s).

From the water absorption coefficient, the diffusion coefficient at US conditions can be derived under the assumption that the diffusion coefficient is almost constant (Klopfer 1974):

$D_{U S}=\left(\frac{A_{b w}}{1.128 \cdot \Delta c}\right)^{2}$

where $D_{U S}$ is the diffusion coefficient of bound water diffusion $\left(\mathrm{m}^{2} \mathrm{~s}^{-1}\right), \Delta c$ the water concentration difference $\left(\mathrm{kg} \mathrm{m}^{-3}\right)$ and 1.128 is equal to $(4 / \pi)^{0.5}$. Thereby, Eq. 4 , converted and applied to water sorption of two opposing faces, corresponds to the calculation of the diffusion coefficient by Teischinger (1987) according to Comstock (1963) and Stamm (1964).

For 'wet cup' conditions, the gradient of the water concentration through the specimen was assumed to be nearly linear as observed by Zwicker (2008) and shown in Figure 2. Therefore, $\Delta c$ was determined by doubling the differences of the mean water concentration at initial and final conditions (Sonderegger and Niemz 2011) as follows:

$\Delta c=2 \cdot\left(c_{\text {end }}-c_{\text {begin }}\right)$

where $c_{\text {end }}$ is the water concentration of the specimen at the end of the experiment $\left(\mathrm{kg} \mathrm{m}^{-3}\right)$ and $c_{\text {begin }}$ the water concentration at the beginning of the experiment $\left(\mathrm{kg} \mathrm{m}^{-3}\right)$, at conditions of $20^{\circ} \mathrm{C} / 65 \%$ $\mathrm{RH}$ and $20^{\circ} \mathrm{C} / 35 \% \mathrm{RH}$, respectively.

For dry cup conditions, a cumulative decrease of the water concentration through the specimen is visible (Figure 2). Therefore, a wood chip approximately $80 \mathrm{~mm} \times 20 \mathrm{~mm} \times 2 \mathrm{~mm}$, was put onto the silica gel during the experiment (Figure 1). Its water concentration $\left(c_{\text {wood.chip }}\right)$ measured at the end of the tests was the data used as the lower water concentration in:

$\Delta c=c_{\text {begin }}{ }^{-} c_{\text {wood.chip }}$

\section{Results and discussion}

\section{Water vapour resistance}

The water vapour resistance factors $\mu$ and their interactions between the principal anatomical directions and correlated by polynomial functions are presented in Figures 3 and 4 and Table 1, while the moisture-dependent data correlated by exponential functions are presented in Figure 5 and Table 2.
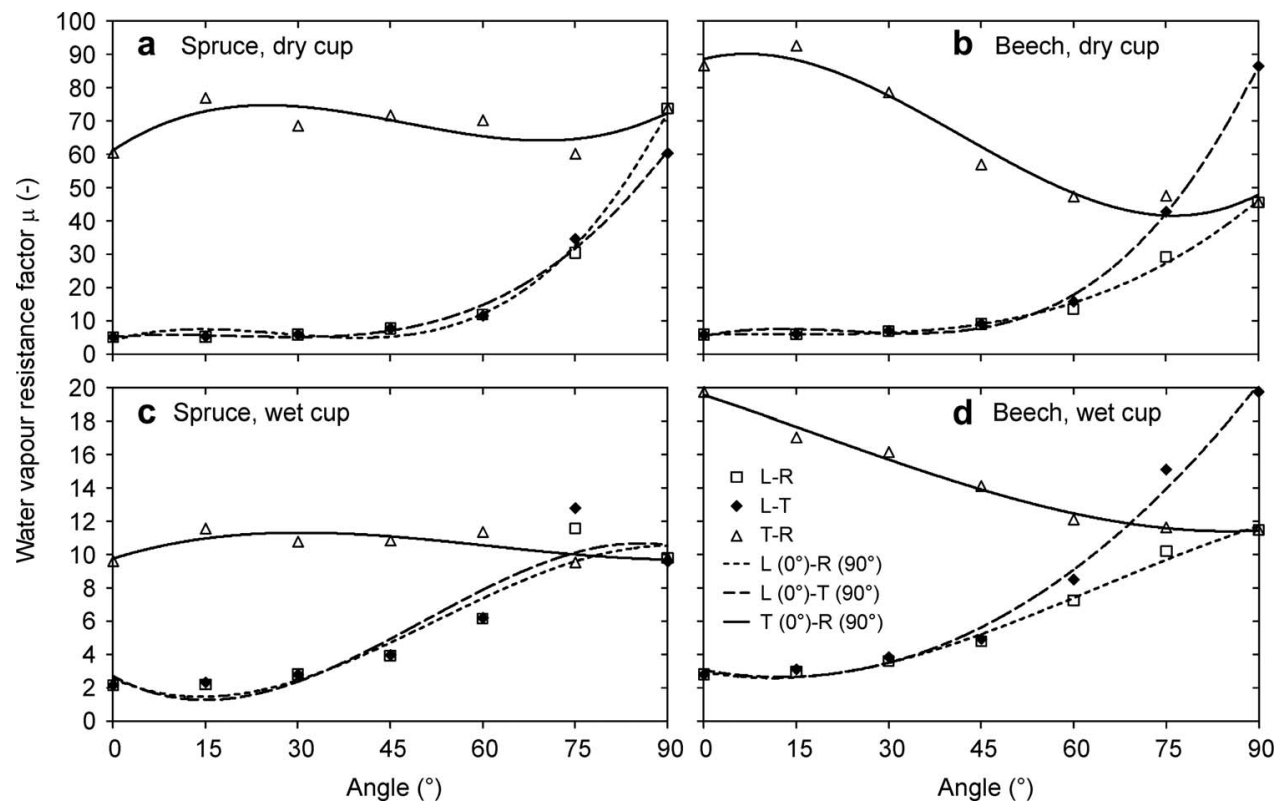

Figure 3 Water vapour resistance factor $\mu$ in and between the principal anatomical directions of Norway spruce (a, c) and European beech (b, d) at 'dry cup' $\left(20^{\circ} \mathrm{C} / 65 \% \mathrm{RH}\right.$ to desiccant) and 'wet cup' conditions $\left(20^{\circ} \mathrm{C} / 65 \% \mathrm{RH}\right.$ to desalinated water). R, radial; $\mathrm{T}$, tangential; L, longitudinal; symbols, measured data; lines, calculated values. 


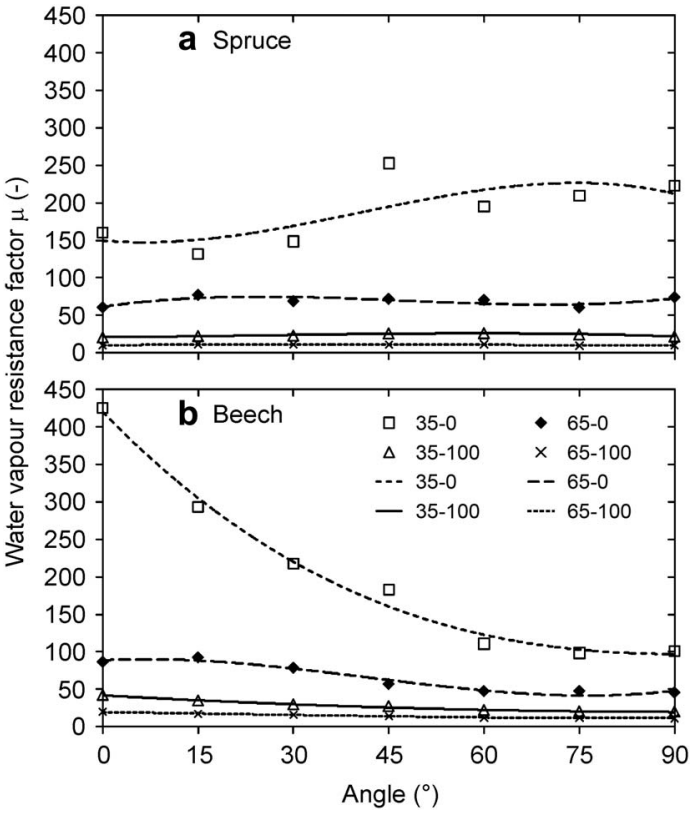

Figure 4 Water vapour resistance factor $\mu$ of Norway spruce (a) and European beech (b) perpendicular to the grain between the tangential $\left(0^{\circ}\right)$ and the radial $\left(90^{\circ}\right)$ directions at different cup conditions. $35-0$ and $65-0=20^{\circ} \mathrm{C} / 35 \% \mathrm{RH}$ and $20^{\circ} \mathrm{C} / 65 \% \mathrm{RH}$ to desiccant, respectively; $35-100$ and $65-100=20^{\circ} \mathrm{C} / 35 \% \mathrm{RH}$ and $20^{\circ} \mathrm{C} / 65 \% \mathrm{RH}$ to desalinated water, respectively; symbols, measured data; lines, calculated values.

Figure 3 shows $\mu$ in and between the three principal anatomical directions for spruce and beech. The trend between two principal directions was determined as a polynomial function of third order. Thereby, according to Bodig and Jayne (1993), the angles between the $\mathrm{L}$ direction and the directions perpendicular to the grain correspond to the grain

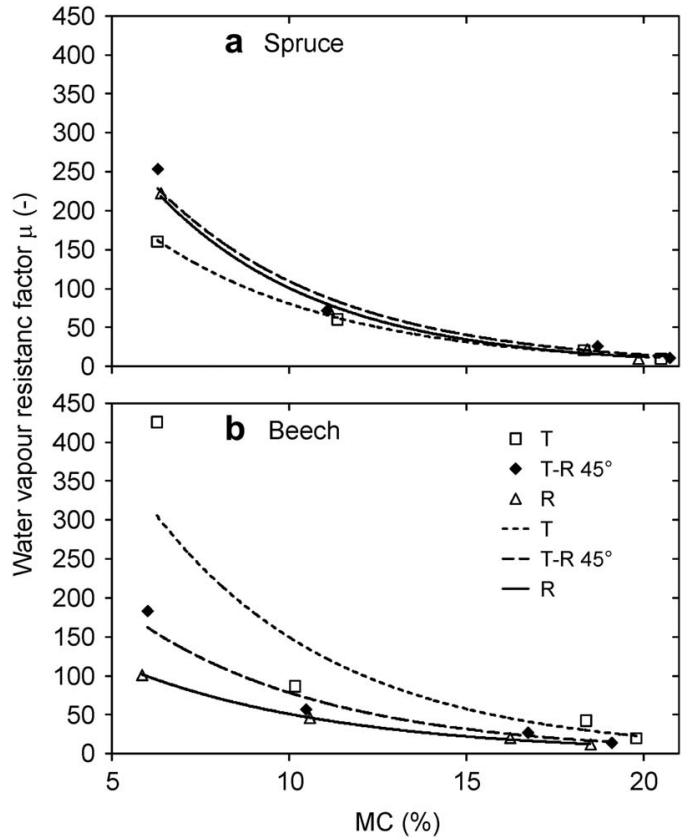

Figure 5 Water vapour resistance factor $\mu$ of Norway spruce (a) and European beech (b) perpendicular to the grain, in the tangential $(\mathrm{T})$ and the radial $(\mathrm{R})$ direction and at an angle of $45^{\circ}$ between these directions ( $\mathrm{T}-\mathrm{R} 45^{\circ}$ ), depending on $\mathrm{MC}$.

angle $\left(\mathrm{L}=0^{\circ}\right.$ and $\mathrm{R}$ and $\left.\mathrm{T}=90^{\circ}\right)$ and the angles between the $\mathrm{T}$ and the $\mathrm{R}$ direction to the ring angle $\left(\mathrm{T}=0^{\circ}\right.$ and $\left.\mathrm{R}=90^{\circ}\right)$.

For spruce, the trends are almost congruent between the $\mathrm{L}$ and $\mathrm{T}$ and the $\mathrm{L}$ and $\mathrm{R}$ direction. In contrast, values of $\mu$ for beech increase to a greater extent from the $\mathrm{L}$ to the $\mathrm{T}$ than to the $\mathrm{R}$ direction, most noticeably at grain angles of $75^{\circ}$ and $90^{\circ}$. At 'wet cup' conditions, $\mu$ increases for both species above a grain angle of $15^{\circ}$. At 'dry cup' conditions

Table 1 Parameters of the polynomial function $\mu=A+B \cdot x+C \cdot x^{2}+D \cdot x^{3}$ describing the water vapour resistance factor $\mu$ (-) between the principal anatomical directions.

\begin{tabular}{lccccccc}
\hline $\begin{array}{l}\text { Wood } \\
\text { species }\end{array}$ & $\begin{array}{c}\text { Condition } \\
(\mathrm{RH} \text { in } \%)\end{array}$ & Diffusion direction & $\mathrm{A}$ & $\mathrm{B}$ & $\mathrm{C}$ & $\mathrm{D}$ & $\mathrm{R}^{2}$ \\
\hline Norway & $65-0$ & $\mathrm{~L}\left(0^{\circ}\right)-\mathrm{R}\left(90^{\circ}\right)$ & 4.18 & 0.532 & $-2.5110^{-2}$ & $3.0710^{-4}$ & 0.995 \\
spruce, & $65-0$ & $\mathrm{~L}\left(0^{\circ}\right)-\mathrm{T}\left(90^{\circ}\right)$ & 5.24 & 0.141 & $-9.7710^{-3}$ & $1.6810^{-4}$ & 0.99 \\
dry cup & $65-0$ & $\mathrm{~T}\left(0^{\circ}\right)-\mathrm{R}\left(90^{\circ}\right)$ & 61.3 & 1.23 & $-3.3410^{-2}$ & $2.3510^{-4}$ & 0.61 \\
& $35-0$ & $\mathrm{~T}\left(0^{\circ}\right)-\mathrm{R}\left(90^{\circ}\right)$ & 150 & -0.743 & $6.1610^{-2}$ & $-5.0710^{-4}$ & 0.55 \\
Norway & $65-100$ & $\mathrm{~L}\left(0^{\circ}\right)-\mathrm{R}\left(90^{\circ}\right)$ & 2.57 & -0.162 & $6.5310^{-3}$ & $-4.1610^{-5}$ & 0.92 \\
spruce, & $65-100$ & $\mathrm{~L}\left(0^{\circ}\right)-\mathrm{T}\left(90^{\circ}\right)$ & 2.72 & -0.204 & $8.0410^{-3}$ & $-5.3310^{-5}$ & 0.87 \\
wet cup & $65-100$ & $\mathrm{~T}\left(0^{\circ}\right)-\mathrm{R}\left(90^{\circ}\right)$ & 9.77 & 0.115 & $-2.5110^{-3}$ & $1.3610^{-5}$ & 0.62 \\
& $35-100$ & $\mathrm{~T}\left(0^{\circ}\right)-\mathrm{R}\left(90^{\circ}\right)$ & 20.6 & 0.0656 & $2.3010^{-3}$ & $-3.2110^{-5}$ & 0.94 \\
European & $65-0$ & $\mathrm{~L}\left(0^{\circ}\right)-\mathrm{R}\left(90^{\circ}\right)$ & 6.11 & 0.0163 & $-2.5710^{-3}$ & $8.1610^{-5}$ & 0.99 \\
beech, & $65-0$ & $\mathrm{~L}\left(0^{\circ}\right)-\mathrm{T}\left(90^{\circ}\right)$ & 5.51 & 0.377 & $-2.0210^{-2}$ & $2.9010^{-4}$ & 0.998 \\
dry cup & $65-0$ & $\mathrm{~T}\left(0^{\circ}\right)-\mathrm{R}\left(90^{\circ}\right)$ & 88.7 & 0.460 & $-3.6310^{-2}$ & $2.9110^{-4}$ & 0.96 \\
& $35-0$ & $\mathrm{~T}\left(0^{\circ}\right)-\mathrm{R}\left(90^{\circ}\right)$ & 420 & -8.71 & $7.3910^{-2}$ & $-1.8910^{-4}$ & 0.99 \\
European & $65-100$ & $\mathrm{~L}\left(0^{\circ}\right)-\mathrm{R}\left(90^{\circ}\right)$ & 2.98 & -0.0710 & $3.5110^{-3}$ & $-1.8310^{-5}$ & 0.99 \\
beech, & $65-100$ & $\mathrm{~L}\left(0^{\circ}\right)-\mathrm{T}\left(90^{\circ}\right)$ & 3.08 & -0.0667 & $2.6410^{-3}$ & $2.3810^{-6}$ & 0.99 \\
wet cup & $65-100$ & $\mathrm{~T}\left(0^{\circ}\right)-\mathrm{R}\left(90^{\circ}\right)$ & 19.6 & -0.122 & $-5.2610^{-4}$ & $9.7610^{-6}$ & 0.99 \\
& $35-100$ & $\mathrm{~T}\left(0^{\circ}\right)-\mathrm{R}\left(90^{\circ}\right)$ & 41.9 & -0.474 & $2.5210^{-3}$ & $-1.1410^{-7}$ & 0.99 \\
\hline
\end{tabular}

$\mathrm{x}$, angle between the directions in degrees; $\mathrm{L}$, longitudinal; $\mathrm{R}$, radial; $\mathrm{T}$, tangential; $\mathrm{R}^{2}$, coefficient of determination. 
Table 2 Parameters of the exponential function $\mu=\mathrm{A} \cdot \mathrm{e}^{\mathrm{B} \cdot \omega}$ describing the water vapour resistance factor $\mu(-)$ depending on MC $\omega(\%)$.

\begin{tabular}{lcccc}
\hline $\begin{array}{l}\text { Wood } \\
\text { species }\end{array}$ & $\begin{array}{l}\text { Diffusion } \\
\text { direction }\end{array}$ & $\mathrm{A}$ & $\mathrm{B}$ & $\mathrm{R}^{2}$ \\
\hline Norway & $\mathrm{T}$ & 526 & -0.188 & 0.99 \\
spruce & $\mathrm{T}-\mathrm{R}\left(45^{\circ}\right)$ & 798 & -0.199 & 0.97 \\
& $\mathrm{R}$ & 854 & -0.214 & 0.98 \\
European & $\mathrm{T}$ & 1012 & -0.191 & 0.90 \\
beech & $\mathrm{T}-\mathrm{R}\left(45^{\circ}\right)$ & 482 & -0.182 & 0.97 \\
& $\mathrm{R}$ & 270 & -0.167 & 0.99 \\
\hline
\end{tabular}

$\mathrm{T}$, tangential; $\mathrm{R}$, radial; $\mathrm{T}-\mathrm{R}\left(45^{\circ}\right)$, angle of $45^{\circ}$ between $\mathrm{R}$ and $\mathrm{T}$; $\mathrm{R}^{2}$, coefficient of determination.

a clear increase of $\mu$ was only found above a grain angle of $60^{\circ}$.

Figure 4 illustrates $\mu$ in and between the $T$ and the $R$ directions at different cup conditions. In the $\mathrm{T}$ direction, $\mu$ of beech is up to four times higher than in the $\mathrm{R}$ direction and decreases up to about $60^{\circ}$ with increasing ring angle. The differences between the $\mathrm{T}$ and the $\mathrm{R}$ directions are greater for dry than for wet cup conditions. These values are in good accordance with measurements by Vanek and Teischinger (1989); however, they are contradictory to results of Kiessl and Möller (1989), who quoted literature data from different sources, where the values in $\mathrm{R}$ direction are higher than in the $\mathrm{T}$ direction both for dry-cup and wet-cup tests. In contrast to beech, $\mu$ of spruce is either equal for both directions or higher in the $\mathrm{R}$ than in the $\mathrm{T}$ direction. The polynomial function depending on the ring angle shows a clearly lower coefficient of determination (Table 1). Higher $\mu$ values for spruce in the $\mathrm{R}$ than in the $\mathrm{T}$ direction are also stated by diverse authors for wet conditions (Kiessl and Möller 1989, Vanek and Teischinger 1989, Zillig et al. 2007). In contrast to our results, this ratio is partly reversed at low MC (Vanek and Teischinger 1989, Zillig et al. 2007).

As presented in Figure 5, $\mu$ decreases exponentially with increasing MC. The highest values and the greatest decrease were found for beech in the T direction, as already stated by Vanek and Teischinger (1989). For spruce, the values in the $\mathrm{R}$ direction are similar to the values at a ring angle of $45^{\circ}$ and they are both higher than in the $\mathrm{T}$ direction up to about $18 \% \mathrm{MC}$.

\section{Combined bound water and water vapour diffusion}

Figures 6-11 show diffusion coefficients for the combined bound water and water vapour diffusion at SS $\left(\mathrm{D}_{\mathrm{SS}}\right)$ and US conditions $\left(\mathrm{D}_{\mathrm{US}}\right)$ in and between the principal anatomical directions of the two species with the corresponding polynomial and exponential function parameters in Tables 3 and 4.

In all directions, $\mathrm{D}_{\mathrm{SS}}$ is about two to three times higher for spruce than for beech, in agreement with the results of Mouchot et al. (2006). In the L direction, it is up to 12 times higher than perpendicular to the grain for spruce, and up to 15 times higher for beech. Similar mean diffusion coefficient ratios between the principal directions are described by Olek et al. (2005) for beech, although the absolute values are about twice as high due to the higher measuring temperature. In contrast, Mouchot et al. (2006) measured up to 36 times higher values in the $\mathrm{L}$ direction than perpendicular to the grain. This may be due to the different test conditions. The relatively low differences of the data between the $\mathrm{L}$ direction and those perpendicular to the grain correspond well with the model of Kang et al. (2008), who integrated water vapour diffusion through pits and rays into the classical diffusion model of Stamm (1960b) and Choong (1965) in Siau (1995). While $\mathrm{D}_{\mathrm{SS}}$ is equal under dry and wet conditions in the $\mathrm{L}$
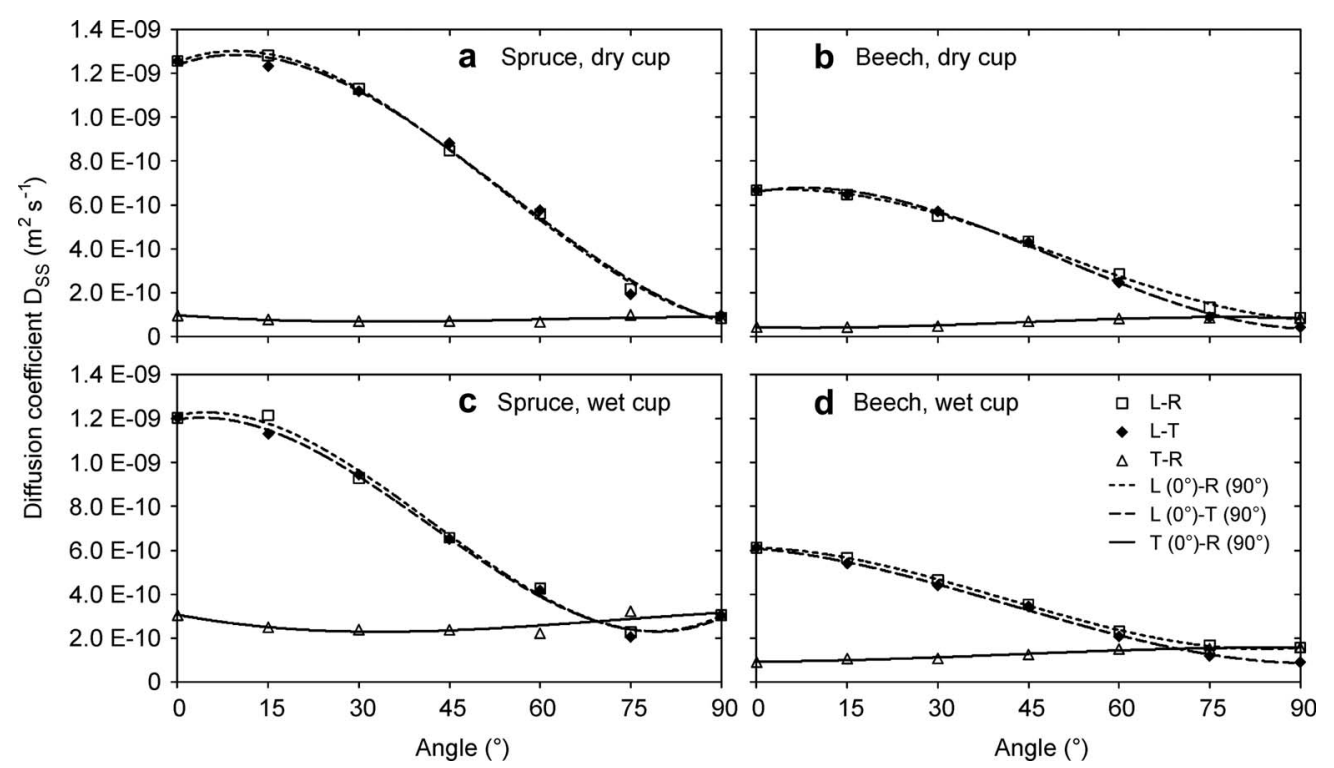

Figure 6 Steady-state-determined diffusion coefficient $\mathrm{D}_{\mathrm{SS}}$ in and between the principal anatomical directions of Norway spruce (a, c) and European beech (b, d) at 'dry cup' $\left(20^{\circ} \mathrm{C} / 65 \% \mathrm{RH}\right.$ to desiccant) and 'wet cup' conditions $\left(20^{\circ} \mathrm{C} / 65 \% \mathrm{RH}\right.$ to desalinated water). $\mathrm{R}$, radial; $\mathrm{T}$, tangential; L, longitudinal; symbols, measured data; lines, calculated values. 


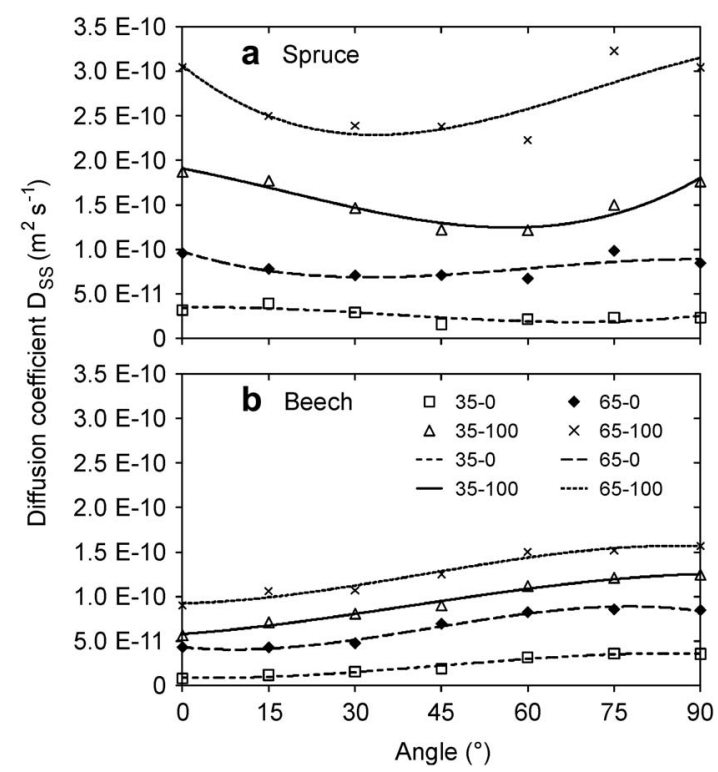

Figure 7 Steady-state-determined diffusion coefficient $D_{\mathrm{SS}}$ of Norway spruce (a) and European beech (b) perpendicular to the grain between the tangential $\left(0^{\circ}\right)$ and the radial $\left(90^{\circ}\right)$ directions at different cup conditions. $35-0$ and $65-0=20^{\circ} \mathrm{C} / 35 \% \mathrm{RH}$ and $20^{\circ} \mathrm{C} /$ $65 \% \mathrm{RH}$ to desiccant, respectively; $35-100$ and $65-100=20^{\circ} \mathrm{C} /$ $35 \% \mathrm{RH}$ and $20^{\circ} \mathrm{C} / 65 \% \mathrm{RH}$ to desalinated water, respectively; symbols, measured data; lines, calculated values.

direction it is, perpendicular to the grain, twice as high for beech and thrice as high for spruce in wet conditions compared to dry conditions (Figure 6).

Perpendicular to the grain (Figure 7), a clear increase of $\mathrm{D}_{\mathrm{SS}}$ with increasing ring angle was found for beech at all considered conditions. For spruce, in contrast, a clear cor-

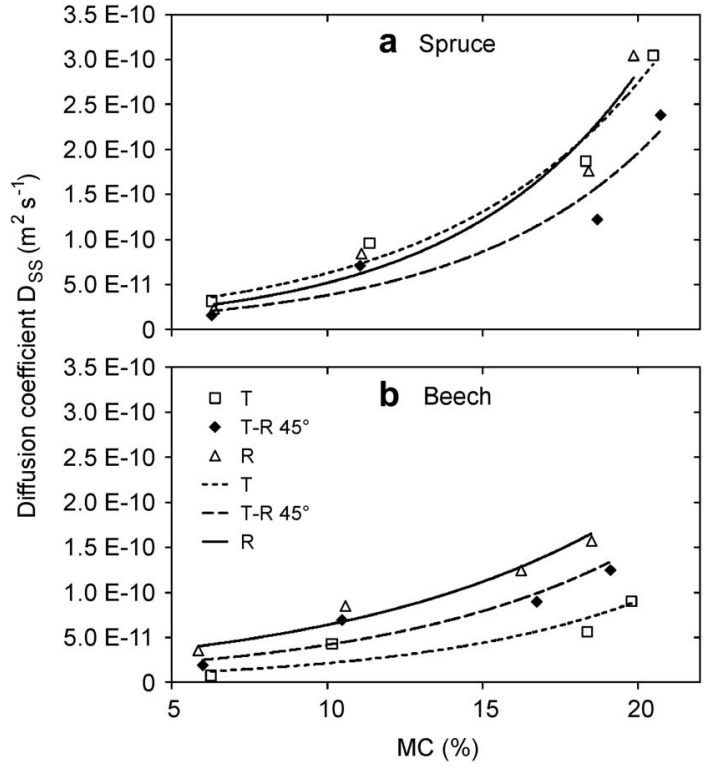

Figure 8 Steady-state-determined diffusion coefficient $D_{S S}$ of Norway spruce (a) and European beech (b) perpendicular to the grain, in the tangential $(\mathrm{T})$ and the radial $(\mathrm{R})$ direction and at an angle of $45^{\circ}$ between these directions ( $\mathrm{T}-\mathrm{R} 45^{\circ}$ ), depending on MC.

relation between $D_{S S}$ and the ring angle is missing; at wet conditions the lowest values were found between ring angles of $30^{\circ}$ and $60^{\circ}$. This can be attributed to the different anatomical composition of the two species and resembles their thermal conductivity behaviour perpendicular to the grain (Sonderegger et al. 2011). Koc et al. (2003) also determined only small differences between the $\mathrm{T}$ and $\mathrm{R}$ diffusion for spruce with, averaged over the whole $\mathrm{MC}$ range, moderately higher values in the $\mathrm{T}$ than in the $\mathrm{R}$ direction.
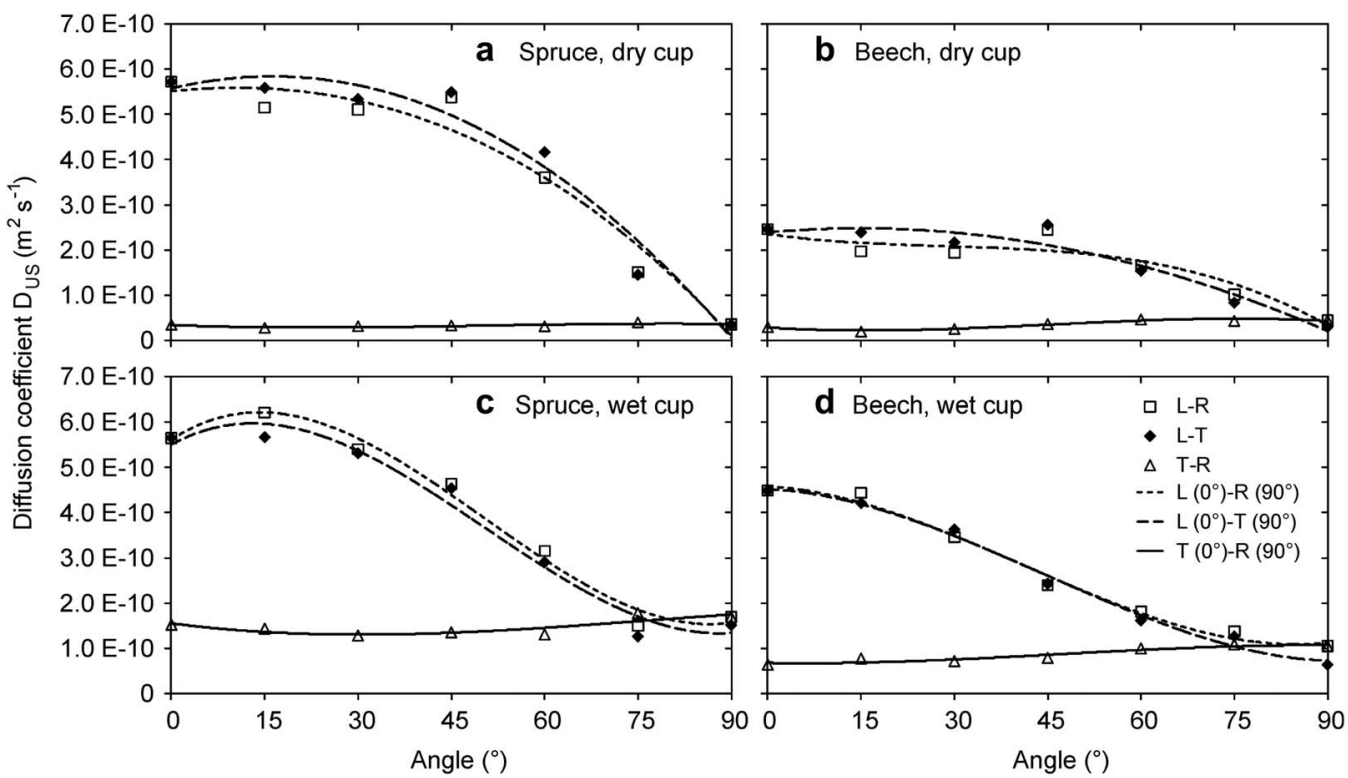

Figure 9 Unsteady-state-determined diffusion coefficient $\mathrm{D}_{\mathrm{US}}$ in and between the principal anatomical directions of Norway spruce (a, c) and European beech (b, d) at 'dry cup' $\left(20^{\circ} \mathrm{C} / 65 \% \mathrm{RH}\right.$ to desiccant) and 'wet cup' conditions $\left(20^{\circ} \mathrm{C} / 65 \% \mathrm{RH}\right.$ to desalinated water). $\mathrm{R}$, radial; $\mathrm{T}$, tangential; L, longitudinal; symbols, measured data; lines, calculated values. 


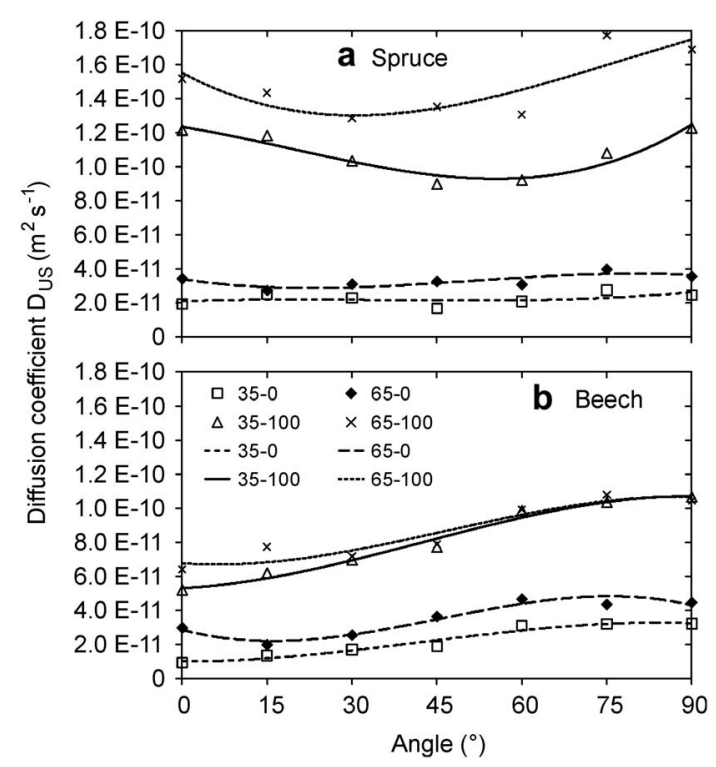

Figure 10 Unsteady-state-determined diffusion coefficient $\mathrm{D}_{\mathrm{US}}$ of Norway spruce (a) and European beech (b) perpendicular to the grain between the tangential $\left(0^{\circ}\right)$ and the radial $\left(90^{\circ}\right)$ directions at different cup conditions. $35-0$ and $65-0=20^{\circ} \mathrm{C} / 35 \% \mathrm{RH}$ and $20^{\circ} \mathrm{C} /$ $65 \% \mathrm{RH}$ to desiccant, respectively; $35-100$ and $65-100=20^{\circ} \mathrm{C} /$ $35 \% \mathrm{RH}$ and $20^{\circ} \mathrm{C} / 65 \% \mathrm{RH}$ to desalinated water, respectively; symbols, measured data; lines, calculated values.

$\mathrm{D}_{\mathrm{US}}$ shows similar tendencies to $\mathrm{D}_{\mathrm{SS}}$, but is averaged over all directions about half as high (Figures 6 and 9). The differences between $D_{S S}$ and $D_{U S}$ are smaller for the specimens that were initially conditioned at $20^{\circ} \mathrm{C}$ and $35 \% \mathrm{RH}$ than at $65 \% \mathrm{RH}$, so that $\mathrm{D}_{\mathrm{SS}}$ and $\mathrm{D}_{\mathrm{US}}$ for beech at a differentiating climate from $35 \% \mathrm{RH}$ to $0 \% \mathrm{RH}$ are almost equal (Figures 7 and 10). In contrast, Wadsö (1993) and Pfriem (2006) show clearly higher differences with a factor of about 10 between $\mathrm{D}_{\mathrm{US}}$ and $\mathrm{D}_{\mathrm{SS}}$, which can be attributed to their modified method (simultaneous diffusion from two opposite sides of the specimen), which is clearly more influenced by the specimen thickness (Teischinger 1987). Additionally, $\mathrm{D}_{\mathrm{US}}$ is influenced by the MC difference of the experiment, which was already stated by Christensen and Kelsey (1959). The very low data by Pfriem et al. (2010) may be ascribed to the above-mentioned influences.

\section{Moisture dependency of diffusion}

Both diffusion coefficients, $D_{S S}$ and $D_{\text {US }}$, increase with increasing MC. This dependency can be described as an approximate exponential function (Stamm 1959; Stamm 1960b; Klopfer 1974; Olek et al. 2005; Mannes et al. 2009; Sonderegger et al. 2010). However, when complex (e.g., multiscale) models are used to describe diffusion properties, the dependency from the MC is more complicated (e.g., Kang et al. 2008, Eitelberger and Hofstetter 2010). Figures 8 and 11 show the relationship between diffusion coefficients and $\mathrm{MC}$ for the $\mathrm{R}$ and $\mathrm{T}$ directions and for a ring angle of $45^{\circ}$, whereas the calculated parameters of the corresponding exponential functions are listed in Table 4. Both diffusion coefficients, $\mathrm{D}_{\mathrm{SS}}$ and $\mathrm{D}_{\mathrm{US}}$, show similar tendencies. The exponential increase with increasing MC highly correlates with the measured data. The correlation is higher for US than for SS diffusion and also higher for spruce than for beech. While the diffusion coefficients for beech increase from the $\mathrm{T}$ direction over a ring angle of $45^{\circ}$ to the $\mathrm{R}$ direction, they are almost congruent in the $\mathrm{T}$ and $\mathrm{R}$ directions for spruce but (as already stated) clearly lower at a ring angle of $45^{\circ}$.

Eq. 4 is only valid for constant diffusion coefficients. Therefore, if the diffusion coefficients increase with increasing $\mathrm{MC}$, as the measurements revealed for spruce and beech, the calculated diffusion coefficient is overestimated for adsorption and underestimated for desorption, although in theory, they should be identical (Klopfer 1974; Crank 1994). In contrast, Comstock (1963) and Teischinger (1987), for example, measured higher values for desorption than for adsorption. According to Comstock (1963), this can be attributed to compression stresses during adsorption and tension stresses during desorption that influence the diffusion process.

\section{Bound water sorption}

Table 5 shows the sorption coefficients of bound water in the three principal anatomical directions. Spruce has similar values for the $\mathrm{R}$ and the $\mathrm{T}$ directions at all measured humidity sectors. For beech, the sorption coefficients are higher in the $\mathrm{R}$ direction than in the $\mathrm{T}$ direction, but the difference between the coefficients of these two directions decreases with increasing RH. The values perpendicular to the grain at 35-100\% RH coincide well with Teischinger's data (1987), who measured about one quarter smaller values for spruce and beech at $35-95 \%$ RH.

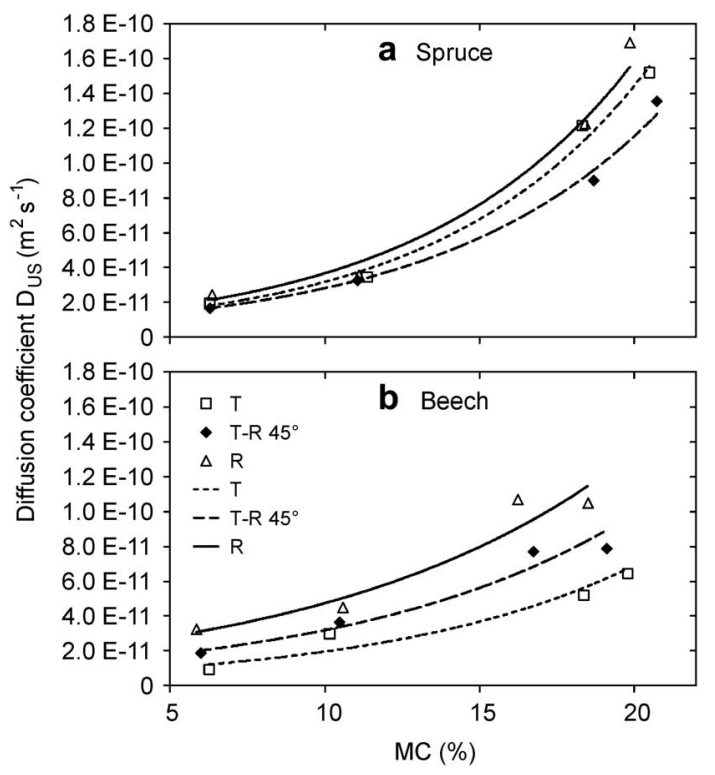

Figure 11 Unsteady-state-determined diffusion coefficient $\mathrm{D}_{\mathrm{US}}$ of Norway spruce (a) and European beech (b) perpendicular to the grain, in the tangential $(\mathrm{T})$ and the radial $(\mathrm{R})$ direction and at an angle of $45^{\circ}$ between these directions ( $\mathrm{T}-\mathrm{R} 45^{\circ}$ ), depending on MC. 


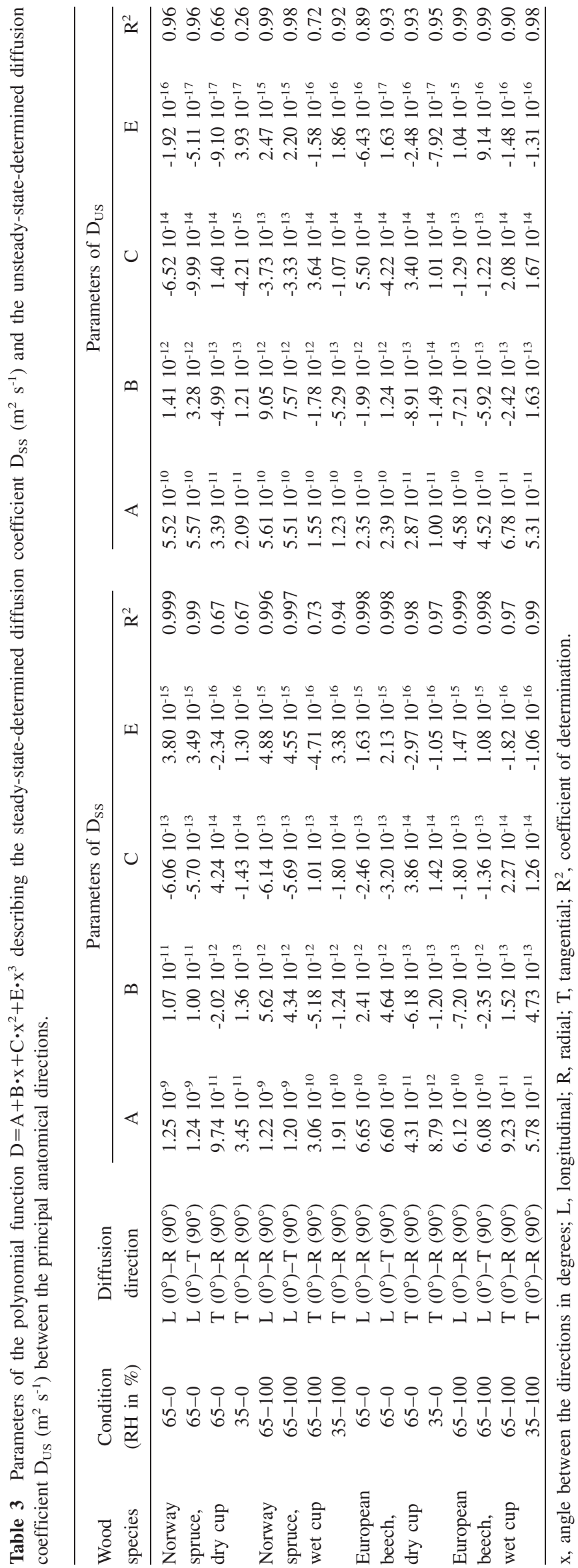


Table 4 Parameters of the exponential function $\mathrm{D}=\mathrm{A} \cdot \mathrm{e}^{\mathrm{B} \cdot \omega}$ describing the steady-state-determined diffusion coefficient $D_{\mathrm{SS}}\left(\mathrm{m}^{2} \mathrm{~s}^{-1}\right)$ and the unsteady-state-determined diffusion coefficient $\mathrm{D}_{\mathrm{US}}\left(\mathrm{m}^{2} \mathrm{~s}^{-1}\right)$ depending on $\mathrm{MC} \omega(\%)$.

\begin{tabular}{|c|c|c|c|c|c|c|c|}
\hline \multirow{2}{*}{$\begin{array}{l}\text { Wood } \\
\text { species }\end{array}$} & \multirow{2}{*}{$\begin{array}{l}\text { Diffusion } \\
\text { direction }\end{array}$} & \multicolumn{3}{|c|}{ Parameters of $D_{\mathrm{SS}}$} & \multicolumn{3}{|c|}{ Parameters of $D_{\mathrm{US}}$} \\
\hline & & A & $\mathrm{B}$ & $\mathrm{R}^{2}$ & A & B & $\mathrm{R}^{2}$ \\
\hline \multirow{3}{*}{$\begin{array}{l}\text { Norway } \\
\text { spruce }\end{array}$} & $\mathrm{T}$ & $1.4310^{-11}$ & 0.148 & 0.97 & $6.9910^{-12}$ & 0.151 & 0.99 \\
\hline & $\mathrm{T}-\mathrm{R}\left(45^{\circ}\right)$ & $7.4410^{-12}$ & 0.164 & 0.91 & $6.8710^{-12}$ & 0.141 & 0.997 \\
\hline & $\mathrm{R}$ & $9.3810^{-12}$ & 0.171 & 0.95 & $8.5110^{-12}$ & 0.146 & 0.98 \\
\hline \multirow{3}{*}{$\begin{array}{l}\text { European } \\
\text { beech }\end{array}$} & $\mathrm{T}$ & $5.0510^{-12}$ & 0.144 & 0.79 & $5.5710^{-12}$ & 0.126 & 0.89 \\
\hline & $\mathrm{T}-\mathrm{R}\left(45^{\circ}\right)$ & $1.1610^{-11}$ & 0.128 & 0.86 & $1.0310^{-11}$ & 0.113 & 0.97 \\
\hline & $\mathrm{R}$ & $2.0910^{-11}$ & 0.112 & 0.95 & $1.6810^{-11}$ & 0.104 & 0.95 \\
\hline
\end{tabular}

$\mathrm{T}$, tangential; $\mathrm{R}$, radial; $\mathrm{T}-\mathrm{R}\left(45^{\circ}\right)$, angle of $45^{\circ}$ between $\mathrm{R}$ and $\mathrm{T} ; \mathrm{R}^{2}$, coefficient of determination.

Table 5 Sorption coefficients of bound water $A_{b w}$ according to Eq. 2 compared with literature values of water absorption by partial immersion $\mathrm{A}_{\mathrm{w}}$ (according to ISO 15148 2002).

\begin{tabular}{|c|c|c|c|c|c|c|}
\hline \multirow[b]{2}{*}{$\begin{array}{l}\text { Wood } \\
\text { species }\end{array}$} & \multirow[b]{2}{*}{$\begin{array}{l}\text { Sorption } \\
\text { direction }\end{array}$} & \multicolumn{4}{|c|}{$\mathrm{RH}(\%)$ sector } & \multirow{2}{*}{$\begin{array}{c}\text { Literature } \\
\text { values } \\
\mathrm{A}_{\mathrm{w}} \\
\left(\mathrm{kg} \mathrm{m}^{-2} \mathrm{~s}^{-0.5}\right)\end{array}$} \\
\hline & & $\begin{array}{c}35-0 \\
\mathrm{~A}_{\mathrm{bw}} \\
\left(\mathrm{kg} \mathrm{m}^{-2} \mathrm{~s}^{-0.5}\right)\end{array}$ & $\begin{array}{c}65-0 \\
\mathrm{~A}_{\mathrm{bw}} \\
\left(\mathrm{kg} \mathrm{m}^{-2} \mathrm{~s}^{-0.5}\right)\end{array}$ & $\begin{array}{c}35-100 \\
\mathrm{~A}_{\mathrm{bw}} \\
\left(\mathrm{kg} \mathrm{m}^{-2} \mathrm{~s}^{-0.5}\right)\end{array}$ & $\begin{array}{c}65-100 \\
\mathrm{~A}_{\mathrm{bw}} \\
\left(\mathrm{kg} \mathrm{m}^{-2} \mathrm{~s}^{-0.5}\right)\end{array}$ & \\
\hline Norway & $\mathrm{R}$ & -0.000159 & -0.000282 & 0.000976 & 0.000625 & 0.003 \\
\hline \multirow[t]{2}{*}{ Spruce } & $\mathrm{T}$ & -0.000140 & -0.000293 & 0.000970 & 0.000642 & 0.004 \\
\hline & $\mathrm{L}$ & - & -0.000885 & - & 0.000374 & 0.018 \\
\hline European & $\mathrm{R}$ & -0.000242 & -0.000498 & 0.001174 & 0.000677 & 0.004 \\
\hline \multirow[t]{2}{*}{ Beech } & $\mathrm{T}$ & -0.000152 & -0.000441 & 0.001044 & 0.000656 & 0.005 \\
\hline & $\mathrm{L}$ & - & -0.001069 & - & 0.000677 & 0.059 \\
\hline
\end{tabular}

${ }^{\mathrm{a}}$ Wang and Niemz 2002.

$\mathrm{R}$, radial; $\mathrm{T}$, tangential; $\mathrm{L}$, longitudinal.

The $\mathrm{L}$ direction shows 2 to 3 times higher values than perpendicular to the grain at the lower $\mathrm{RH}$ sector $(65-0 \%$ $\mathrm{RH})$, whereas at the higher $\mathrm{RH}$ sector $(65-100 \% \mathrm{RH})$ they are equal (beech) or lower (spruce) than in the $\mathrm{T}$ or $\mathrm{R}$ directions. This is due to the fact that these test conditions have the EMC of the differentiating climate closer to the initial climate for the specimens tested in the $\mathrm{L}$ direction than perpendicular to the grain (Vecellio 2009).

The water absorption by partial immersion (liquid water uptake) according to Wang and Niemz (2002) shows, by comparison, values from about 3 times higher (spruce, $\mathrm{R}$ direction, 35-100\% RH) up to 87 times higher (beech, L direction, 65-100\% RH) than bound water sorption (Table 5).

\section{Conclusions}

In this study, diffusion properties were determined not only in the principal anatomical directions but also between these directions in $15^{\circ}$ steps. Spruce and beech show clear different dependencies with regard to the anatomical directions.

Furthermore, the study points out that measurements of the SS and US diffusion coefficients of the same specimen differ by about a factor of 2 . Therefore, both diffusion coefficients have to be measured for model calculations in the field of building physics. The US-determined diffusion coef- ficient is required to describe short-term water storage at alternating indoor climates. The SS-determined diffusion coefficient should be applied for long-term and constant moisture gradients through an external wall (caused for example by a temperature gradient in the winter).

\section{References}

Bodig, J., Jayne, B.A. Mechanics of wood and wood composites. Krieger Publishing Company, Malabar, Florida, 1993.

Choong, E.T. (1965) Diffusion coefficients of softwoods by steadystate and theoretical methods. Forest Prod. J. 15:21-27.

Comstock, G.L. (1963) Moisture diffusion coefficients in wood as calculated from adsorption, desorption, and steady state data. Forest Prod. J. 13:97-103.

Crank, J. The mathematics of diffusion. $2^{\text {nd }}$ edition. Clarendon Press, Oxford, 1994.

Christensen, G.N., Kelsey, K.E. (1959) Die Geschwindigkeit der Wasserdampfsorption durch Holz. Holz Roh- Werkst. 17:178188.

Eitelberger, J., Hofstetter, K. (2010) Multiscale homogenization of wood transport properties: diffusion coefficients for steady-state moisture transport. Wood Material Science and Engineering 5:97-103.

Frandsen, H.L., Damkilde, L., Svensson, S. (2007) A revised multiFickian moisture transport model to describe non-Fickian effects in wood. Holzforschung 61:563-572. 
Hankinson, R.L. Investigation of crushing strength of spruce at varying angles of grain. Air Force Information Circular No. 259, U.S. Air Service, 1921.

Hofstetter, K., Eberhardsteiner, J., Stürzenbecher, R., Hackspiel, C. (2009) Wood and wood products-linking multiscale analysis and structural numerical simulations. In: Proceedings of the $7^{\text {th }}$ European LS-DYNA Conference, DYNAmore GmbH, pp. 24-34.

Hozjan, T., Svensson, S. (2011) Theoretical analysis of moisture transport in wood as an open porous hygroscopic material. Holzforschung 65:97-102.

ISO 12572 (2001) Hygrothermal performance of building materials and products - determination of water vapour transmission properties. Geneva.

ISO 15148 (2002) Hygrothermal performance of building materials and products - determination of water absorption coefficient by partial immersion. Geneva.

Jošč́a, M., Sonderegger, W., Niemz, P. (2010) Wärme- und Feuchtetransport in Holzbauelementen unter freier Bewitterung. Bauphysik 32:308-318.

Kang, W., Kang, C.W., Chung, W.Y., Eom, C.D., Yeo, H. (2008) The effect of openings on combined bound water and water vapor diffusion in wood. J. Wood Sci. 54:343-348.

Kiessl, K., Möller, U. (1989) Zur Berechnung des Feuchteverhaltens von Bauteilen aus Holz und Holzwerkstoffen. Selektion feuchtetechnischer Stoffeigenschaften. Holz Roh- Werkst. 47:317322.

Koc, P., Houška, M., Štok, B. (2003) Computer aided identification of the moisture transport parameters in spruce wood. Holzforschung 57:533-538.

Klopfer, H. Wassertransport durch Diffusion in Feststoffen. Bauverlag, Wiesbaden/Berlin, 1974.

Mannes, D., Sonderegger, W., Hering, S., Lehmann, E., Niemz, P. (2009) Non-destructive determination and quantification of diffusion processes in wood by means of neutron imaging. Holzforschung 63:589-596.

Mouchot, N., Thiercelin, F., Perre, P., Zoulalian, A. (2006) Characterization of diffusional transfers of bound water and water vapor in beech and spruce. Maderas. Cienc. Tecnol. 8:139-147.

Olek, W. (2003) Analysis of the cup method application for determination of the bound water diffusion coefficient in wood. Folia Forestalia Polonica, Serie B 34:15-25.

Olek, W., Perré, P., Weres, J. (2005) Inverse analysis of the transient bound water diffusion in wood. Holzforschung 59:38-45.

Pfriem, A. Untersuchungen zum Materialverhalten thermisch modifizierter Hölzer für deren Verwendung im Musikinstrumentenbau. Dissertation, Technische Universität Dresden, 2006.

Pfriem, A., Zauer, M., Wagenführ, A. (2010) Alteration of the unsteady sorption behaviour of maple (Acer pseudoplatanus L.) and spruce (Picea abies (L.) Karst.) due to thermal modification. Holzforschung 64:235-241.
Siau, J.F. Wood: influence of moisture on physical properties. Virginia Polytechnic Institute and State University, Keene NY, USA, 1995.

Sonderegger, W., Niemz, P. (2009) Thermal conductivity and water vapour transmission properties of wood-based materials. Eur. J. Wood Prod. 67:313-321.

Sonderegger, W., Niemz, P. (2011) Thermal and moisture flux in soft fibreboards. Eur. J. Wood Prod., DOI: 10.1007/s00107010-0498-7.

Sonderegger, W., Hering, S., Mannes, D., Vontobel, P., Lehmann, E., Niemz, P. (2010) Quantitative determination of bound water diffusion in multilayer boards by means of neutron imaging. Eur. J. Wood Prod. 68:341-350.

Sonderegger, W., Hering, S., Niemz, P. (2011) Thermal behaviour of Norway spruce and European beech in the principal anatomical directions. Holzforschung 65:369-375.

Stamm, A.J. (1959) Bound-water diffusion into wood in the fiber direction. Forest Prod. J. 9:27-32.

Stamm, A.J. (1960a) Bound-water diffusion into wood in acrossthe-fiber directions. Forest Prod. J. 10:524-528.

Stamm, A.J. (1960b) Combined bound water and water vapor diffusion into sitka spruce veneer. Forest Prod. J. 10:644-648.

Stamm A.J. (1964) Wood and cellulose science. The Ronald Press Company, New York.

Teischinger, A. Feuchtigkeitsausgleichende Wirkung von Holz in Innenräumen. Dissertation, Universität für Bodenkultur, Wien 1987.

Vanek, M., Teischinger, A. (1989) Diffusionskoeffizienten und Diffusionswiderstandszahlen von verschiedenen Holzarten. Holzforsch. Holzverw. 41:3-6.

Vecellio, M. Untersuchungen zur Wasserdampfdiffusion von Buche und Fichte. Bachelor's thesis, Institute for Building Materials (Wood Physics), ETH Zurich, 2009.

Wadsö, L. (1993) Measurements of water vapour sorption in wood. Part 2. Results. Wood Sci. Technol. 28:59-65.

Wang, X., Niemz, P. (2002) Untersuchungen zur Bestimmung der Wasseraufnahmekoeffizienten von $\mathrm{Holz}$ in den drei Hauptschnittrichtungen. Fachzeitschrift Holz 54:32.

Zillig, W., Derome, D., Diepens, J., Carmeliet, J. (2007) Modelling hysteresis of wood. Proceedings of the $12^{\text {th }}$ Symposium for Building Physics, Vol. 1, $29^{\text {th }}$ to $31^{\text {st }}$ March 2007, Dresden, pp. 406-413.

Zwicker, P. Untersuchungen zum Diffusionsverhalten von Holz und Holzwerkstoffen. Bachelor's thesis, Institute for Building Materials (Wood Physics), ETH Zurich, 2008.

Received August 26, 2010. Accepted April 4, 2011.

Previously published online June 1, 2011. 